\title{
Application of a new methodology for the synthesis and resolution of a $\beta$-(thien-2-yl) proline with the 7-azanorbornane skeleton
}

\author{
Ana M. Gil, ${ }^{a}$ Pilar López, ${ }^{a}$ Elena Buñuel, ${ }^{* b}$ and Carlos Cativiela $*^{a}$ \\ ${ }^{a}$ Departamento de Química Orgánica, ICMA, Universidad de Zaragoza-CSIC, 50009 \\ Zaragoza, Spain \\ E-mail: cativiela@unizar.es \\ ${ }^{b}$ Departamento de Química Orgánica, Universidad Autónoma de Madrid, 28049 Madrid, Spain \\ E-mail: elena.bunnuel@uam.es
}

\section{Dedicated to Professor José Elguero on the occasion of his $70^{\text {th }}$ birthday, and to Professor Pedro Molina on his $60^{\text {th }}$ anniversary}

(received 22 Dec 04; accepted 10 Feb 05; published on the web 22 Feb 05)

\begin{abstract}
The enantiomers of a heavily constrained proline derivative, methyl $(1 S, 2 R, 4 R)$ - and $(1 R, 2 S, 4 S)$ 2-(thien-2-yl)-7-azabicyclo [2.2.1] heptane-1-carboxylate, have been obtained separately by resolution of the racemic mixture using chiral high performance liquid chromatography. This is a particular example of the application of our new methodology, which takes advantage of the efficiency of chromatographic resolution techniques for the preparation of both enantiomers of a broad variety of proline- $\alpha$-amino acid chimeras with a 7 -azanorbornane skeleton.
\end{abstract}

Keywords: Proline, constrained $\alpha$-amino acids, 7-azabicyclo[2.2.1]heptane, chiral HPLC

\section{Introduction}

The introduction of conformational constraints constitutes one of the most promising approaches to the construction of peptide analogues of pharmaceutical interest. ${ }^{1}$ Furthermore, it has become a useful tool for the elucidation of biologically active conformations ${ }^{1 \mathrm{a}, 2}$ by providing information about the spatial requirements for optimal interaction with receptors., ${ }^{2,3}$

Several $\beta$-substituted prolines (Figure 1) have been synthesized as amino acid chimeras in which the functional groups of the amino acid side-chain are combined with the conformational restrictions characteristic of the cyclic amino acid residue. ${ }^{4}$ Replacement of the natural amino acids in peptides with such proline- $\alpha$-amino acid chimeras has led to better understanding of the bioactive conformations of cholecystokinin, ${ }^{5}$ angiotensin II, ${ }^{6}$ bradykinin, ${ }^{7}$ and opioid peptides. ${ }^{8,9}$ 
Also, $\beta$-alkylproline analogues have served for the development of enzyme inhibitors, ${ }^{9,10}$ as well as peptidomimetics exhibiting improved bioactivity and greater metabolic stability. ${ }^{6-9}$

The proline analogues which contain a 7-azabicyclo[2.2.1] heptane structure, $\mathbf{R} \mathbf{b}_{7}$ Pro, constitute a distinct class of amino acids, owing to their extra conformational restriction (Figure 1). Hence, the benefits of the parent compound $(\mathrm{R}=\mathrm{H})$, as a replacement for proline in a boroarginine thrombin inhibitor, ${ }^{11}$ and as starting material in the synthesis of a new class of HIV1 protease inhibitor, ${ }^{12}$ have already been proved. Moreover, we have already described the synthesis of a proline-L-phenylalanine chimera analogue in enantiomerically pure form, methyl (1S,2S,4R)-N-benzoyl-2-phenyl-7-azabicyclo[2.2.1] heptane-1-carboxylate, and its incorporation into a model dipeptide, Bz-Phb ${ }_{7}$ Pro-L-Phe-NH ${ }^{i}{ }{ }^{13}{ }^{13}$ The X-ray diffraction analysis on this dipeptide $^{14}$ revealed that, in the solid state, this constrained peptide containing the azanorbornane proline adopted a type I $\beta$-turn whereas the analogous dipeptide sequence incorporating L-proline has been shown to accommodate a $\beta$ II-turn disposition.

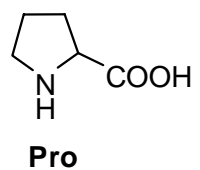

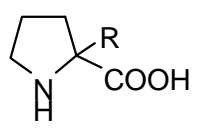

Pro- $\alpha$-amino acid chimeras $\mathrm{R}=$ amino acid side chain

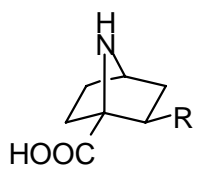

$\mathrm{Rb}_{7}$ Pro

Figure 1. Structure of proline and some constrained analogues.

On the other hand, the increasing interest in these nitrogen-containing, heavily constrained heterocyclic amino acids is, to a large extent, caused by the current extensive use of a simple proline as an asymmetric catalyst in a variety of reactions, such as aldol, Mannich, Michael, Diels-Alder, and the $\alpha$-oxidation of aldehydes. ${ }^{15}$

We now report the synthesis of a heavily constrained proline derivative, methyl $N$-benzoyl-2exo-(thien-2-yl)-7-azabicyclo[2.2.1]heptane-1-carboxylate, and the resolution of its racemic mixture using chiral high performance liquid chromatography.

\section{Results and Discussion}

At present, there are few examples of the asymmetric synthesis of prolines with a 7azanorbornane skeleton, ${ }^{16,17}$ the literature reports only two resolution procedures to obtain the two enantiomers of a 7-azanorbornane proline separately. One of them consists in the formation of diastereomers and subsequent separation by crystallization, which involves the introduction of additional synthetic steps to the pathway towards the final products. ${ }^{18}$ On the other hand, we have already developed a highly efficient and simple resolution method for an azanorbornane proline-phenylalanine chimera analogue, methyl $N$-benzoyl-2-exo-phenyl-7-azabicyclo-[2.2.1]heptane-1-carboxylate, by chiral high performance liquid chromatography (HPLC). ${ }^{13}$ 
Therefore, we first embarked on the preparation of a racemic mixture of methyl $N$-benzoyl-2exo-(thien-2-yl)-7-azabicyclo[2.2.1] heptane-1-carboxylate. Its synthesis was performed by applying the methodology that we had developed previously. ${ }^{13,17,19,20}$ Our overall strategy is based on building the 7-azabicyclo[2.2.1]heptane skeleton by intramolecular nucleophilic displacement of a 4-aminocyclohexanol derivative, proceeding from the cycloadducts provided by the Diels-Alder reaction of C-4 unsaturated 5(4H)-oxazolones and Danishefsky's diene.

First, the synthesis of the unsaturated C-4 oxazolone, $(Z)$-2-phenyl-4-(thien-2-ylmethylene)$5(4 H)$-oxazolone $(1 \mathrm{Z})$ was accomplished by condensation of hippuric acid ( $N$-benzoylglycine) and 2-thiophenecarboxaldehyde, according to the procedure described in the literature (Scheme $1)^{21}$
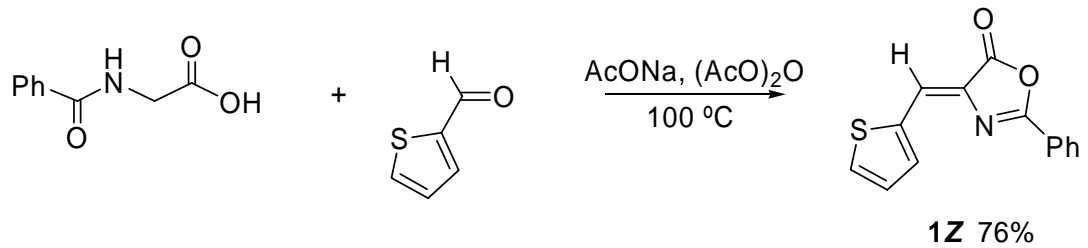

\section{Scheme 1}

Then, the Diels-Alder reaction of Danishefsky's diene and the oxazolone $\mathbf{1 Z}$ was tested; after 2 days' refluxing in toluene complete conversion of the oxazolone was achieved. Hydrolysis of the adduct mixture gave a mixture of two compounds, rac-2, proceeding from the adducts resulting from the endo- and exo- attacks of the diene, in 92\% combined yield (Scheme 2). Subsequent elimination of the methoxy group with oxazolone- ring-opening, by treatment of the hydrolyzed adducts with DBU in methanol, led to rac-3 in $68 \%$ yield.

Next, a number of reagents and conditions was tested for hydrogenating the double bond of the enone rac-3. A homogeneous procedure, using Wilkinson's catalyst, did not give complete conversion, even after prolonged reaction (9 days). However, the use of zinc in acetic acid led to the desired hydrogenated compound rac-4 in low yield (50\%). Finally, heterogeneous hydrogenation using $20 \% \mathrm{Pd}(\mathrm{OH})_{2} / \mathrm{C}$ in dichloromethane and slight heating $\left(30^{\circ} \mathrm{C}\right)$, proved to be very efficient, affording the ketone rac-4 in nearly quantitative yield. This compound, rac-4, is the precursor of the trans-aminocyclohexanol derivative needed to achieve our goal.

The preparation of the desired 4-hydroxyamino- derivative involved conversion of the ketone function in the cyclohexanone ring into a hydroxy group. Moreover, for the subsequent cyclization, the hydroxy and benzamido groups on the cyclohexane skeleton were required to adopt axial positions, which requires the synthesis of the kinetically controlled alcohol. Several studies have demonstrated that the use of bulky reducing agents at low temperatures produces stereoselective processes that provide preferentially the kinetically controlled product. Accordingly, we decided to use lithium tri-sec-butylborohydride (L-Selectride ${ }^{\circledR}$ ), which offers highly favorable formation of axial alcohols. Thus, reduction of the cyclohexanone derivative rac-4 with L-Selectride ${ }^{\circledR}$ in $\mathrm{THF}$ at $-78^{\circ} \mathrm{C}$ gave the axial- and equatorial- alcohols, rac-5 
(stereoselectivity ratio: $77 / 23$ ), in $96 \%$ combined yield. The ratio of stereoisomers in the crude reaction mixture was determined by integration of the ${ }^{1} \mathrm{H}$ - NMR signals of the two isomers, at $3.05 \mathrm{ppm}(\mathrm{ddd}, 1 \mathrm{H}, J=14.0 \mathrm{~Hz}, J=3.7 \mathrm{~Hz}, J=3.7 \mathrm{~Hz})$ and $3.35 \mathrm{ppm}(\mathrm{ddd}, 1 \mathrm{H}, J=14.3 \mathrm{~Hz}, J=$ $3.7 \mathrm{~Hz}, J=3.7 \mathrm{~Hz}$ ). Initially, the compound showing a signal at $3.05 \mathrm{ppm}$ was assumed to be the axial isomer, rac-5a; subsequent cyclization of its mesyl derivative, rac-6a, confirmed this.

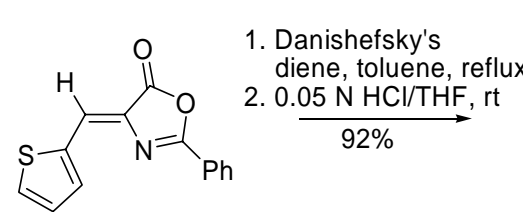

$1 Z$

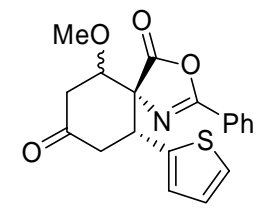

rac-2

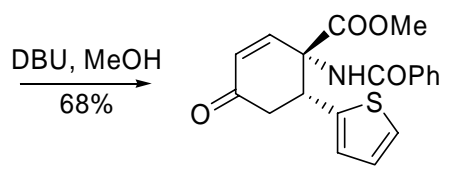

rac-3
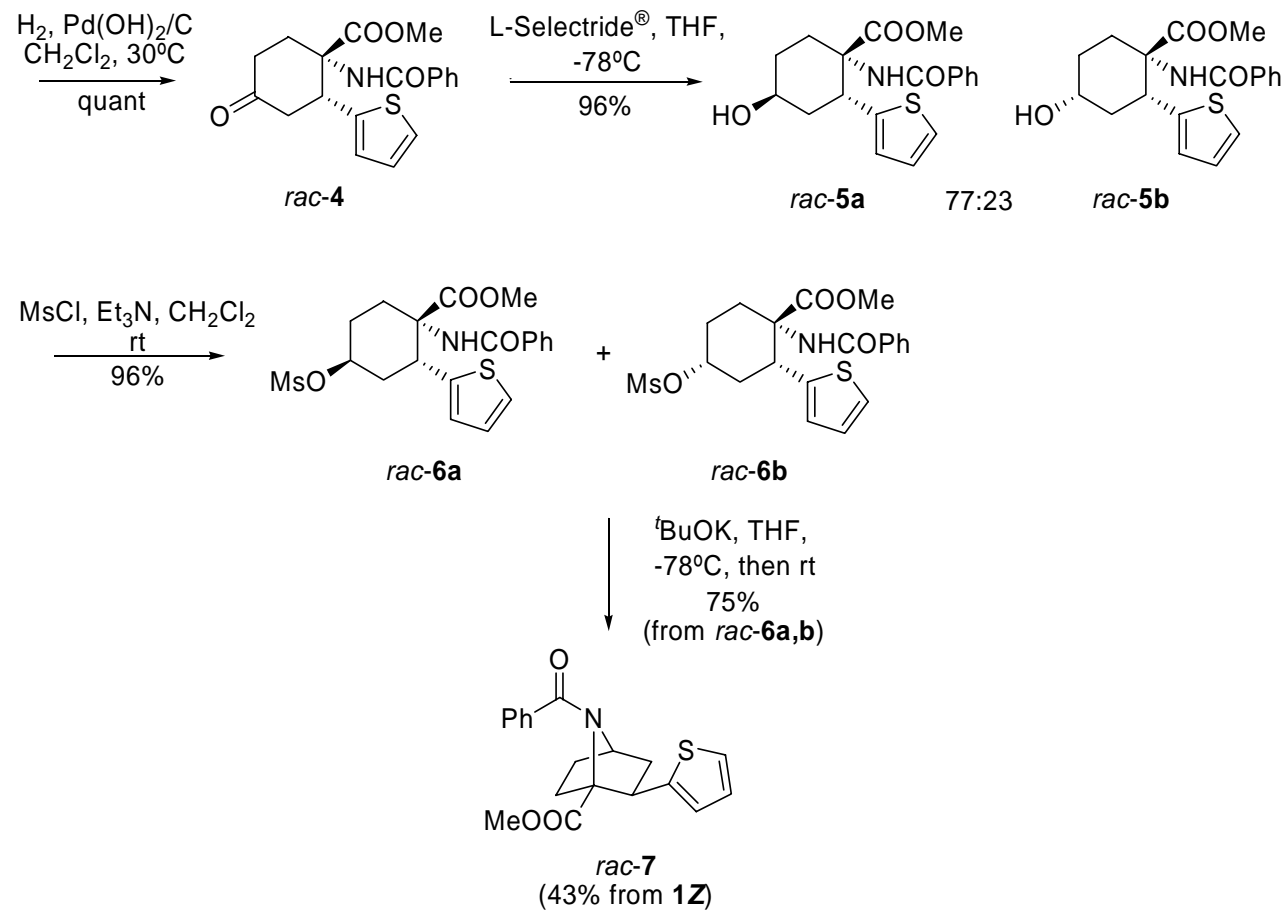

\section{Scheme 2}

The mixture of the alcohols rac-5 was transformed cleanly into a mixture of the corresponding methanesulfonate derivatives, rac-6a and $\mathbf{6 b}$, in $96 \%$ yield by treatment with methanesulfonyl chloride in triethylamine. Furthermore, this methanesulfonate mixture was purified by column chromatography and provided pure samples of both isomers, which were fully characterized.

The cyclization of 4-aminocyclohexanol derivatives has become one of the most widely reported procedures for creating 7-azabicyclo[2.2.1] heptane rings. ${ }^{22}$ Base-promoted internal nucleophilic displacement of the methanesulfonate group had already been achieved by treatment with potassium tert-butoxide in THF. The same reaction conditions were applied to the mixture of methanesulfonates rac-6. Finally, the separation of the product $\mathrm{rac}-7$ from the non- 
cyclizable methanesulfonate rac-6b was easily achieved by column chromatography, which provided methyl $N$-benzoyl-2-exo-(thien-2-yl)-7-azabicyclo[2.2.1] heptane-1-carboxylate (rac-7) in excellent yield (75\% from a 77/23 mixture of rac-6a and $\mathbf{6 b}$ ). In this way, the synthesis was accomplished on a multi-gram scale and $c a$. $1.5 \mathrm{~g}$ of a racemic mixture of rac-7 could be obtained from oxazolone $1 \mathrm{Z}$ in seven steps and $43 \%$ overall yield.

\section{HPLC resolution of $\mathrm{rac}^{-7}$}

Once the synthesis of the racemic compound $\mathrm{rac}-7$ was achieved, we undertook the preparation of the enantiomerically pure form by HPLC resolution using a chiral stationary phase. Specifically, a non-commercial polysaccharide-derived support consisting of mixed 10undecenoate/3,5-dimethylphenylcarbamate of cellulose covalently attached to allylsilica gel was used. $^{23}$ The excellent chiral discrimination exhibited by this stationary phase towards a variety of compounds, together with its high chemical stability, make it especially suitable for resolutions on a preparative scale. We had already shown the efficacy of this methodology for resolving racemic mixtures of constrained phenylalanine analogues. ${ }^{13,24}$

The resolution of rac-7 was initially investigated on an analytical scale (eluent: 95/5 $n$ hexane/2-propanol, $k_{1}^{\prime}=1.81, \alpha=1.58, R_{s}=3.70$ ). From these satisfactory results, the optimal separation conditions on the preparative scale were determined by adding a certain amount of chloroform to the eluent to enhance the solubility of the compound.

Finally, the separation was performed using a 93/2/5 mixture of $n$-hexane/chloroform/2propanol as the eluent (flow-rate $18 \mathrm{~mL} \mathrm{~min}^{-1}$ ) on a $150 \times 20 \mathrm{~mm}$ ID column filled with the 10 undecenoate/3,5-dimethylphenylcarbamate of cellulose bonded on allylsilica gel (see Figure 2).

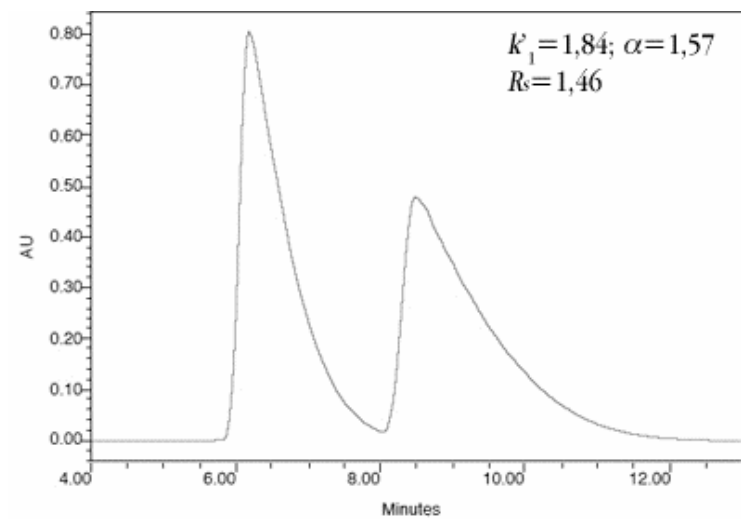

Figure 2. Preparative chromatographic HPLC resolution of rac-7. Column: $150 \times 20 \mathrm{~mm}$ ID, eluent: $n$-hexane/chloroform/2-propanol (93/2/5), flow- rate: $18 \mathrm{~mL} \mathrm{~min}^{-1}$. UV detection at 285 $\mathrm{nm}$. Injection of $40 \mathrm{mg}$ of $\mathrm{rac}-7$ in $0.2 \mathrm{~mL}$ of chloroform. See Experimental Section for definition of the chromatographic parameters.

Under these conditions, working with the repetitive injection mode (see Figure 3), HPLC resolution of rac-7 (1 g) in chloroform $(5 \mathrm{~mL})$ was achieved, with successive injections of $200 \mu \mathrm{L}$. A total of 27 injections was required, with one injection being performed every $11 \mathrm{~min}$. 


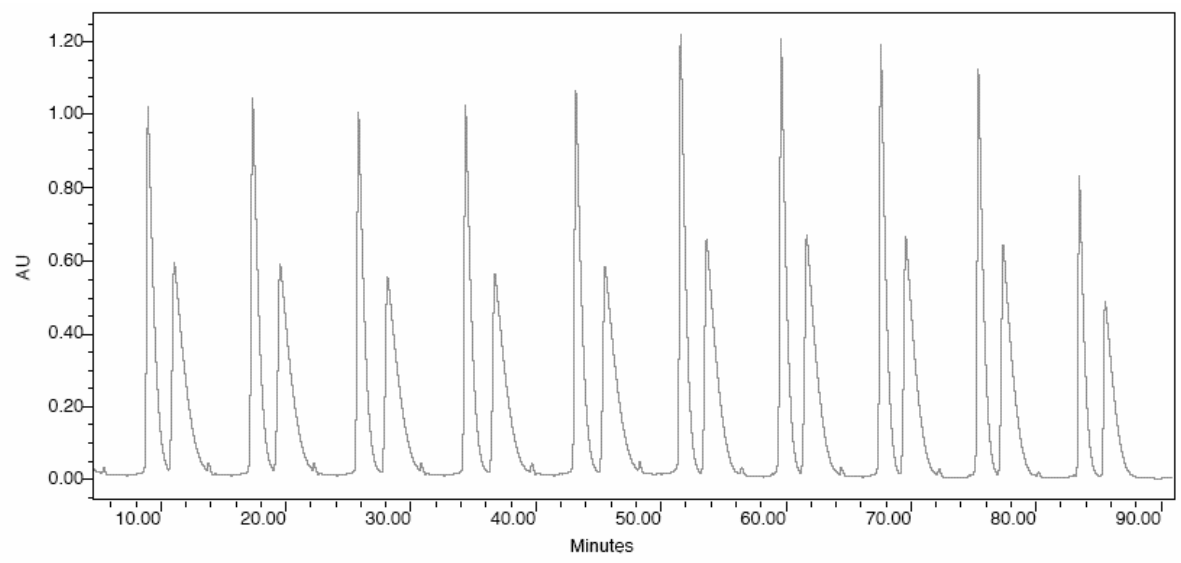

Figure 3. HPLC resolution of $r a c-7$ on preparative scale by repetitive injection mode.

Three separate fractions were collected. Evaporation of the first fraction provided $460 \mathrm{mg}$ of the enantiopure first-eluted enantiomer. The third fraction contained $375 \mathrm{mg}$ of the last eluted enantiomer, in a 99.7/0.3 enantiomeric ratio. The second fraction (51 mg) contained a 62/38 mixture of the first- and the second- eluted enantiomers.

The optical purity of the resolved enantiomers was assessed at the analytical level (Figure 4).

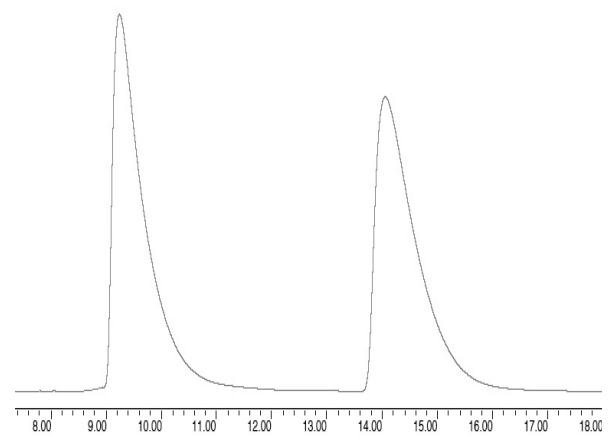

a)

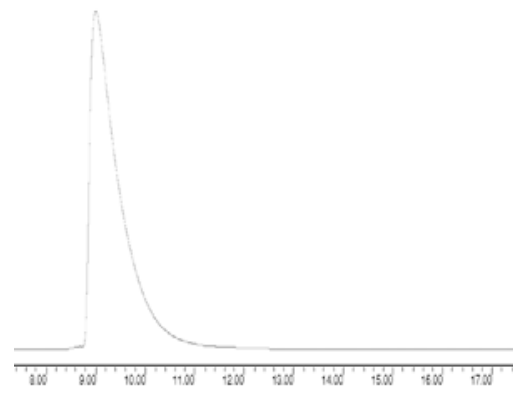

b)

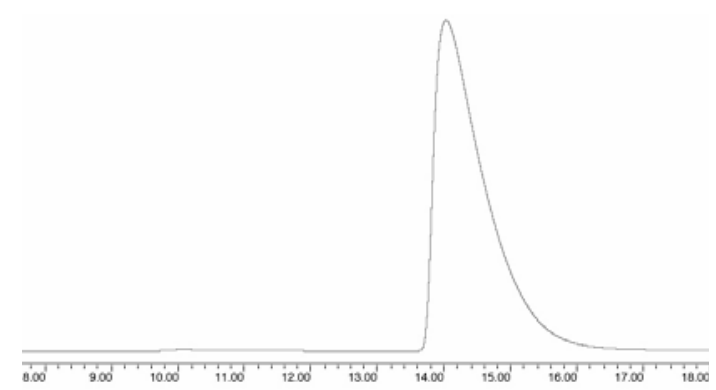

c)

Figure 4. Evaluation of the optical purity of the resolved enantiomers: a) racemic mixture; b) first- eluted enantiomer; c) second- eluted enantiomer. Column: $150 \times 4.6 \mathrm{~mm}$ ID, eluent: $n$ hexane/2-propanol (95/5), flow- rate: $1 \mathrm{~mL} \mathrm{~min}^{-1}$. UV detection at $230 \mathrm{~nm}$. 
To summarize, the resolution of $1 \mathrm{~g}$ of $\mathrm{rac}-7$ finally resulted in $492 \mathrm{mg}$ of the optically pure first- eluted enantiomer and $395 \mathrm{mg}$ of the second- eluted enantiomer in $99.4 \%$ enantiomeric purity.

\section{Assignment of absolute configurations}

Initially the assignment of absolute configuration was tried by X-ray diffraction analysis of a single crystal obtained from a solution of one of the diastereomeric dipeptides resulting from coupling of the racemic mixture with an L-phenylalanine derivative, in the way we have already described for the proline-phenylalanine chimera analogue. ${ }^{13}$ Thus, saponification of rac-7 using potassium hydroxide in methanol led to the corresponding acid, and subsequent coupling of this racemic mixture with enantiomerically pure L-phenylalanine isopropylamide, using the reagent designed by Castro et al., (1H-benzotriazol-1-yloxy)tris(dimethylamino)phosphonium hexafluorophosphate (BOP), gave a mixture of two diastereomeric dipeptide derivatives. After complete separation of the dipeptides by column chromatography, both compounds were obtained individually. However, all attempts to obtain a crystal suitable for single-crystal X-ray analysis, from either of the two resulting diastereomeric dipeptides, failed.

We then decided to assign the absolute configuration by transformation of the enantiomeric $\beta$-(thien-2-yl) derivatives into the corresponding proline-aspartic acid chimeras (Scheme 3).

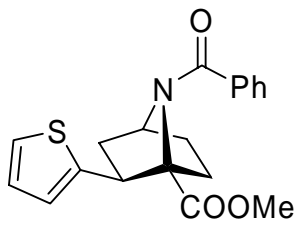

Second eluted enantiomer $(1 R, 2 S, 4 S)-7$

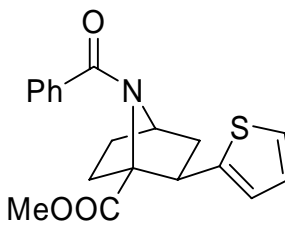

rac-7
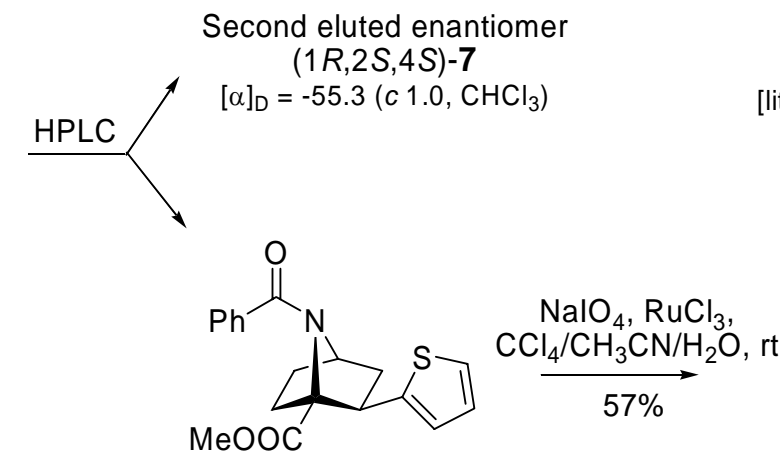

First eluted enantiomer

$(1 S, 2 R, 4 R)-7$

$[\alpha]_{D}=+57.4\left(\right.$ c 1.0, $\left.\mathrm{CHCl}_{3}\right)$
$\mathrm{NaIO}_{4}, \mathrm{RuCl}_{3}$,

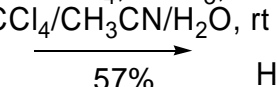
HOOC

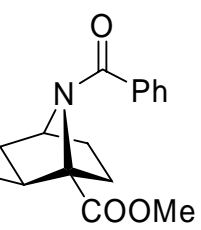

(+)-(1R,2S,4S)-8

$[\alpha]_{D}=+23.0(c 0.2, \mathrm{MeOH})$ $\left[\right.$ lit $^{13}[\alpha]_{D}=+22.3($ c $\left.0.2, \mathrm{MeOH})\right]$

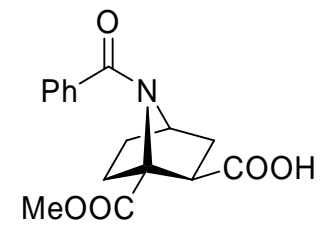

$$
\begin{gathered}
(-)-(1 S, 2 R, 4 R)-8 \\
{[\alpha]_{D}=-23.5(\text { c } 0.2, \mathrm{MeOH})} \\
{\left[\operatorname{lit}^{13}[\alpha]_{D}=-24.1(\text { c } 0.2, \mathrm{MeOH})\right]}
\end{gathered}
$$

\section{Scheme 3}

Oxidative cleavage of the thienyl substituent on the azabicyclic ring of the first- and the secondly- eluting enantiomers of 7 proceeded in 57\% yield, and led to the proline-aspartic acid 
chimera analogues $(1 S, 2 R, 4 R)-\mathbf{8}$ and $(1 R, 2 S, 4 S)-\mathbf{8}$, respectively. The establishment of the absolute configuration for each enantiomer of $\mathbf{8}$ was carried out by determination of the specific rotations and comparison with the corresponding data for the same compounds characterized previously (Scheme 3). ${ }^{13}$ In this way, the first- eluted enantiomer could be identified as that having the $(1 S, 2 R, 4 R)$ configuration, and the second one as $(1 R, 2 S, 4 S)$.

\section{Conclusions}

A versatile and efficient methodology has been applied for the synthesis of a new chimera, a combination of $\alpha$-amino acids and a proline constrained by a 7-azanorbornane skeleton. Cycloaddition of (Z)-2-phenyl-4-(thien-2-ylmethylene)-5(4H)-oxazolone and Danishefsky's diene followed by manipulation of the resulting adducts has led to the synthesis of a racemic mixture of methyl $N$-benzoyl-2-exo-(thien-2-yl)-7-azabicyclo[2.2.1]heptane-1-carboxylate. Furthermore, the high efficacy of the HPLC resolution of this compound has provided the two enantiomers of this constrained proline. This proline is a very special kind of amino acid where the rigidity provided by the azabicyclic skeleton is combined with the presence of a $\beta$ substituent, which mimics the $\alpha$-amino acid side-chain. These proline- $\alpha$-amino acid chimeras are new surrogates to be incorporated into peptides whose structural and biological properties shed light upon the nature of the effects induced by this type of conformational restriction and the influence of the absolute configurations of the stereogenic centers. Their use in the area of catalysis, as replacements for proline, could result in fascinating applications for these heavily constrained amino acids.

\section{Experimental Section}

General Procedures. Melting points were determined using a Büchi SMP-20 apparatus. IR spectra were registered on a Mattson Genesis FTIR spectrophotometer; $v_{\max }$ is given for the main absorption bands. ${ }^{1} \mathrm{H}$ - and ${ }^{13} \mathrm{C}$ - NMR spectra were recorded on a Varian Unity-300 or a Bruker ARX-300 at room temperature, using the residual solvent signal as internal standard. Optical rotations were measured in a $10 \mathrm{~cm}$ cell at $25^{\circ} \mathrm{C}$ using a JASCO P-1020 polarimeter. Elemental analyses were carried out on a Perkin-Elmer $200 \mathrm{C}, \mathrm{H}, \mathrm{N}, \mathrm{S}$ analyzer. TLC was performed on Polygram $^{\circledR}$ sil G/UV254 precoated silica gel polyester plates, with visualization under UV light (254 nm), anisaldehyde or phosphomolybdic acid developers. Column chromatography used silica gel (Kieselgel 60). (Z)-2-Phenyl-4-[thien-2-ylmethylene]-5(4H)-oxazolone (1Z) was prepared by condensation of hippuric acid (benzoylglycine) and 2-thiophenecarboxaldehyde in the presence of anhydrous sodium acetate and acetic anhydride. ${ }^{21}$

HPLC was carried out on a system equipped with a Waters 600-E pump and a Waters 991 photodiode array detector. The preparation of the chiral stationary phase, consisting of mixed 10- 
undecenoate/3,5-dimethylphenylcarbamate of cellulose covalently attached to allylsilica gel, has been described. The solvents used as mobile phases were of spectral grade. HPLC analytical assays were carried out on a $150 \times 4.6 \mathrm{~mm}$ ID column with an eluent flow rate of $1 \mathrm{~mL} \mathrm{~min}{ }^{-1}$ and UV monitoring at $230 \mathrm{~nm}$. The capacity $\left(k_{\mathrm{r}}^{\prime}\right)$, selectivity $(\alpha)$ and resolution $\left(R_{s}\right)$ factors are defined as follows: $k_{\mathrm{r}}^{\prime}=\left(\mathrm{t}_{\mathrm{r}}-\mathrm{t}_{0}\right) / \mathrm{t}_{0}, \alpha=k_{2}^{\prime}{ }_{2} / k^{\prime}{ }_{1}, R_{s}=1.18 \times\left(\mathrm{t}_{2}-\mathrm{t}_{1}\right) /\left[\left(\mathrm{w}_{1 / 2}\right)_{2}+\left(\mathrm{w}_{1 / 2}\right)_{1}\right]$, where subscripts 1 and 2 refer to the first- and second- eluted enantiomer, respectively, $t_{\mathrm{r}}(\mathrm{r}=1,2)$ are their retention times, and $\left(\mathrm{w}_{1 / 2}\right)_{1}$ and $\left(\mathrm{w}_{1 / 2}\right)_{2}$ denote their half-height peak-widths; $\mathrm{t}_{0}$ is the dead time. The preparative resolution of $\mathrm{rac}-7$ was carried out on a $150 \times 20 \mathrm{~mm}$ ID column. A mixture of $n$ hexane/chloroform/2-propanol (93/2/5) was used as the eluent, at a flow rate of $18 \mathrm{~mL} \mathrm{~min}^{-1}$. UV detection was at $285 \mathrm{~nm}$. RT denotes room temperature.

Methyl 2-methoxy-4-oxo-t-6-(thien-2-yl)cyclohexane-r-1-spiro\{4'[2'-phenyl-5'(4'H)-oxazolone]\} (rac-2). Danishefsky's diene $(6.7 \mathrm{~g}, 39.2 \mathrm{mmol})$ was added to a stirred solution of (Z)-2phenyl-4-[thien-2-ylmethylene]-5(4H)-oxazolone $(1 Z)(5.0 \mathrm{~g}, 19.6 \mathrm{mmol})$ in dry toluene $(300 \mathrm{~mL})$ under argon and the mixture was kept under reflux for $48 \mathrm{~h}$. The solvent was then evaporated under vacuum to give a mixture of cycloadducts. The residue was dissolved in THF $(240 \mathrm{~mL})$ and a $0.05 \mathrm{M}$ solution of hydrochloric acid $(60 \mathrm{~mL})$ was added. The reaction mixture was stirred for $4 \mathrm{~h}$ at room temperature and neutralized with saturated $\mathrm{NaHCO}_{3}$. The organic solvent was then evaporated, the residue diluted with dichloromethane $(200 \mathrm{~mL})$, and the organic layer washed with water $(3 \times 100 \mathrm{~mL})$. The organic layer was dried over anhydrous magnesium sulfate, filtered, and the solvent evaporated under vacuum. Flash chromatography on silica-gel using $n$-hexane/ethyl acetate (6/4) as eluent afforded the mixture of the inseparable hydrolyzed cycloadducts rac-2 (6.3 g, $17.7 \mathrm{mmol})$ in 92\% yield from oxazolone $\mathbf{1 Z}$.

Methyl 1-benzamido-4-oxo-t-6-(thien-2-yl)-2-cyclohexene-r-1-carboxylate (rac-3). To a solution of 2-methoxy-4-oxo-t-6-(thien-2-yl)cyclohexane- $r$-1-spiro\{4'[2'-phenyl-5' $\left(4^{\prime} H\right)$ oxazolone]\}, rac-2, (5.2 g, $14.6 \mathrm{mmol})$ in methanol $(100 \mathrm{~mL})$ at $0^{\circ} \mathrm{C}$ was added 1,8 diazabicyclo[5.4.0] undec-7ene, DBU, $(2.2 \mathrm{~g}, 14.6 \mathrm{mmol})$ and the mixture was stirred for $48 \mathrm{~h}$ at $0^{\circ} \mathrm{C}$. After evaporation of the solvent, the residue was purified by flash chromatography on silica gel using $n$-hexane/ethyl acetate (7/3) as eluent to afford the unsaturated ketone rac-3 (3.5 g, $9.9 \mathrm{mmol})$ as a white solid in $68 \%$ yield. $\mathrm{Mp}=124-125^{\circ} \mathrm{C}$. IR (Nujol) $v\left(\mathrm{~cm}^{-1}\right): 3292,1736$, 1690, 1637, 1541. ${ }^{1} \mathrm{H}-\mathrm{NMR}\left(\mathrm{CDCl}_{3}\right) \delta(\mathrm{ppm}): 7.58-7.60(\mathrm{~m}, 2 \mathrm{H}), 7.48-7.52(\mathrm{~m}, 1 \mathrm{H}), 7.38-7.41$ (m, 2H), 7.26-7.30 (m, 2H), $7.03(\mathrm{dd}, 1 \mathrm{H}, J=5.1 \mathrm{~Hz}, J=3.4 \mathrm{~Hz}), 6.97$ (d, 1H, J=3.4 Hz), 6.69 (brs, 1H), $6.30(\mathrm{~d}, 1 \mathrm{H}, J=10.2 \mathrm{~Hz}), 4.39$ (dd, 1H, $J=8.5 \mathrm{~Hz}, J=5.1 \mathrm{~Hz}), 3.83$ (s, 3H), 3.05 (dd, $1 \mathrm{H}, J=16.9 \mathrm{~Hz}, J=8.5 \mathrm{~Hz}), 2.94(\mathrm{dd}, 1 \mathrm{H}, J=16.9 \mathrm{~Hz}, J=5.1 \mathrm{~Hz}) .{ }^{13} \mathrm{C}-\mathrm{NMR}\left(\mathrm{CDCl}_{3}\right) \delta$ (ppm): 196.1, 170.9, 167.5, 145.8, 139.9, 133.2, 132.2, 130.1, 128.7, 127.4, 127.2, 127.0, 126.2, 61.7, 53.5, 43.4, 41.0. Anal. Calcd. for $\mathrm{C}_{19} \mathrm{H}_{17} \mathrm{NO}_{4} \mathrm{~S}$ : C 64.21, H 4.82, N 3.94, S: 9.02; Found: C 64.15, H 4.73, N 3.81, S: 8.94\%.

Methyl 1-benzamido-4-oxo-t-2-(thien-2-yl)cyclohexane-r-1-carboxylate (rac-4). A solution of methyl 1-benzamido-4-oxo-t-6-(thien-2-yl)-2-cyclohexene-r-1-carboxylate, $r a c-3 \quad(3 \mathrm{~g}$, $8.5 \mathrm{mmol})$, in dichloromethane $(30 \mathrm{~mL})$ was hydrogenated at atmospheric pressure for $24 \mathrm{~h}$ at 
$30^{\circ} \mathrm{C}$ using $20 \% \mathrm{Pd}(\mathrm{OH})_{2} / \mathrm{C}(450 \mathrm{mg})$ as catalyst. Removal of the catalyst by filtration (Celite pad) and evaporation of the solvent under vacuum gave rac-4 as a white solid in nearly quantitative yield. $\mathrm{Mp}=69-71^{\circ} \mathrm{C}$. IR (Nujol) $v\left(\mathrm{~cm}^{-1}\right): 1731,1716,1657,1516 .{ }^{1} \mathrm{H}-\mathrm{NMR}$ $\left(\mathrm{CDCl}_{3}\right) \delta$ 7.66-7.70 (m, 2H), 7.48-7.54 (m, 1H), 7.39-7.44 (m, 2H), $7.27(\mathrm{~d}, 1 \mathrm{H}, J=5.1 \mathrm{~Hz})$, $7.02(\mathrm{dd}, 1 \mathrm{H}, J=5.1 \mathrm{~Hz}, J=3.7 \mathrm{~Hz}), 6.89(\mathrm{~d}, 1 \mathrm{H}, J=3.7 \mathrm{~Hz}), 6.42$ (brs, 1H), $4.22(\mathrm{dd}, 1 \mathrm{H}, J=$ $7.7 \mathrm{~Hz}, J=7.7 \mathrm{~Hz}), 3.73(\mathrm{~s}, 3 \mathrm{H}), 3.17-3.27(\mathrm{~m}, 1 \mathrm{H}), 2.86-2.92(\mathrm{~m}, 2 \mathrm{H}), 2.48-2.59(\mathrm{~m}, 3 \mathrm{H}) .{ }^{13} \mathrm{C}-$ NMR $\left(\mathrm{CDCl}_{3}\right) \delta: 207.4,172.3,168.4,140.5,134.2,132.0,128.8,127.6,126.9,126.1,125.5$, 77.4, 77.1, 76.7, 62.8, 52.9, 44.6, 43.5, 36.8, 30.2. Anal. Calcd. for $\mathrm{C}_{19} \mathrm{H}_{19} \mathrm{NO}_{4} \mathrm{~S}: \mathrm{C} 63.85, \mathrm{H}$ 5.36, N 3.92, S: 8.97; Found: C 64.01, H 5.29, N 4.02, S 9.12\%.

Methyl 1-benzamido-4-hydroxy-t-2-(thien-2-yl)cyclohexane-r-1-carboxylate (rac-5). Methyl 1-benzamido-4-oxo-t-2-(thien-2-yl)cyclohexane- $r$-1-carboxylate, $r a c-4$, (3.0 g, $8.4 \mathrm{mmol})$ was dissolved in dry THF $(150 \mathrm{~mL})$ and L-Selectride ${ }^{\circledR}(9.2 \mathrm{~mL}$ of $1 M$ solution in THF, $9.2 \mathrm{mmol})$ was added very slowly at $-78^{\circ} \mathrm{C}$ under an inert atmosphere. After $1 \mathrm{~h}$ stirring at the same temperature, the reaction was quenched by addition of sat. aq. $\mathrm{NH}_{4} \mathrm{Cl}$ and allowed to warm to RT. The solution was concentrated under reduced pressure, extracted with dichloromethane $(3 \times 100 \mathrm{~mL})$ and the combined organic layer were washed with water $(3 \times 50 \mathrm{~mL})$. Drying over anhydrous $\mathrm{MgSO}_{4}$, filtration, and evaporation of solvent in vacuo afforded the crude residue as a $77 / 23$ axial/equatorial mixture. The residue was chromatographed on silica gel, eluting with hexane/ethyl acetate $(3 / 7)$, to give rac-5 $(2.8 \mathrm{~g}, 7.8 \mathrm{mmol})$ as a mixture of two diastereomeric alcohols in $96 \%$ combined yield.

Methyl 1-benzamido-4-O-mesyl-t-2-(thien-2-yl)cyclohexane-r-1-carboxylate (rac-6). The mixture of alcohols obtained from the reduction of ketone rac-4 with L-Selectride ${ }^{\circledR}$, methyl 1benzamido-4-hydroxy-t-2-(thien-2-yl)cyclohexane-r-1-carboxylate, rac-5, (2.5 g, $6.9 \mathrm{mmol}$ ) was dissolved in dry dichloromethane $(100 \mathrm{~mL})$ under an inert atmosphere at RT. Triethylamine $(1.4 \mathrm{~g}, 13.8 \mathrm{mmol})$ and methanesulfonyl chloride $(1.6 \mathrm{~g}, 13.8 \mathrm{mmol})$ were added, to this solution and the resulting mixture stirred at RT. After $24 \mathrm{~h}$, the solvent was removed under vacuum, the residue dissolved in dichloromethane $(100 \mathrm{~mL})$ and washed with water $(3 \times 50 \mathrm{~mL})$. The organic layer was dried over anhydrous $\mathrm{MgSO}_{4}$ and filtered. Solvent removal under reduced pressure provided a mixture $77 / 23$ of the two methanesulfonates rac-6a and $\mathbf{6 b}$. The residue was chromatographed on silica gel, eluting with $n$-hexane/ethyl acetate (4/6), which provided rac-6a and $6 \mathbf{b}(2.9 \mathrm{~g}, 6.6 \mathrm{mmol})$ in $96 \%$ combined yield, and allowed the separation of analytical samples for the total characterization of each product.

Methyl 1-benzamido-c-4-O-mesyl-t-2-(thien-2-yl)cyclohexane-r-1-carboxylate (rac-6a). Mp $=134-135^{\circ} \mathrm{C}$. IR (Nujol) $v\left(\mathrm{~cm}^{-1}\right): 3411,1724,1659,1514 .{ }^{1} \mathrm{H}-\mathrm{NMR}\left(\mathrm{CDCl}_{3}\right) \delta 7.65-7.68(\mathrm{~m}$, 2H), 7.45-7.50 (m, 1H), 7.37-7.42 (m, 2H), $7.25(\mathrm{dd}, 1 \mathrm{H}, J=5.5 \mathrm{~Hz}, J=1.1 \mathrm{~Hz}), 7.00(\mathrm{dd}, 1 \mathrm{H}$, $J=5.1 \mathrm{~Hz}, J=3.7 \mathrm{~Hz}), 6.86-6.87(\mathrm{~m}, 1 \mathrm{H}), 6.23(\mathrm{~s}, 1 \mathrm{H}), 5.11-5.13(\mathrm{~m}, 1 \mathrm{H}), 4.04(\mathrm{dd}, 1 \mathrm{H}, J=$ $12.1 \mathrm{~Hz}, J=4.0 \mathrm{~Hz}), 3.65(\mathrm{~s}, 3 \mathrm{H}), 3.22-3.29(\mathrm{~m}, 1 \mathrm{H}), 3.04(\mathrm{~s}, 3 \mathrm{H}), 2.23-2.52$ (m, 3H), 1.99$2.06(\mathrm{~m}, 1 \mathrm{H}), 1.79-1.90(\mathrm{~m}, 1 \mathrm{H}) .{ }^{13} \mathrm{C}-\mathrm{NMR}\left(\mathrm{CDCl}_{3}\right) \delta 172.2,168.5,140.8,134.6,131.8,128.6$, $127.5,126.8,125.7,125.1,76.5,64.1,52.5,39.6,38.7,33.4,25.9,25.0$. Anal. Calcd. for $\mathrm{C}_{20} \mathrm{H}_{23} \mathrm{NO}_{6} \mathrm{~S}_{2}$, C 54.90, H 5.30, N 3.20, S: 14.66; Found: C 55.01, H 5.22, N 3.12, S 14.73\%. 
Methyl 1-benzamido-t-4-O-mesyl-t-2-(thien-2-yl)cyclohexane-r-1-carboxylate (rac-6b). Mp $=152-153^{\circ} \mathrm{C}$. IR (Nujol) $v\left(\mathrm{~cm}^{-1}\right): 3423,1724,1673,1518 .{ }^{1} \mathrm{H}-\mathrm{NMR}\left(\mathrm{CDCl}_{3}\right) \delta 7.64-7.66(\mathrm{~m}$, 2H), 7.43-7.47 (m, 1H), 7.35-7.39 (m, 2H), 7.20 (dd, 1H, $J=5.0 \mathrm{~Hz}, J=1.0 \mathrm{~Hz}), 6,96(\mathrm{dd}, 1 \mathrm{H}$, $J=5,0 \mathrm{~Hz}, J=3,5), 6.82$ (d, $1 \mathrm{H}, J=3.5 \mathrm{~Hz}$ ), 6.20 (br. s, $1 \mathrm{H}), 4.75-4.83$ (m, 1H), 3.68 (dd, $1 \mathrm{H}, J$ $=13.4 \mathrm{~Hz}, J=3.5 \mathrm{~Hz}), 3.57(\mathrm{~s}, 3 \mathrm{H}), 3.45(\mathrm{ddd}, 1 \mathrm{H}, J=14.4 \mathrm{~Hz}, J=3.8 \mathrm{~Hz}, J=3.3 \mathrm{~Hz}), 2.96$ (s, $3 \mathrm{H}), 2.40-2.46(\mathrm{~m}, 1 \mathrm{H}), 2.17-2.67(\mathrm{~m}, 1 \mathrm{H}), 2.06-2.15(\mathrm{~m}, 2 \mathrm{H}), 1.70-1.80(\mathrm{~m}, 1 \mathrm{H}) .{ }^{13} \mathrm{C}-\mathrm{NMR}$ $\left(\mathrm{CDCl}_{3}\right) \delta 172.3,168.2,140.1,134.5,131.8,128.7,127.5,126.8,125.5,125.3,78.3,63.4,52.6$, 44.1, 38.8, 34.6, 28.8, 27.1. Anal. Calcd. for $\mathrm{C}_{20} \mathrm{H}_{23} \mathrm{NO}_{6} \mathrm{~S}_{2}$ : C 54.90, H 5.30, N 3.20, S: 14.66; Found C: 54.79, H: 5.25, N: 3.10, S: 14.52 .

Methyl $N$-benzoyl-2-exo-(thien-2-yl)-7-azabicyclo[2.2.1]heptane-1-carboxylate (rac-7). To a solution of the 77/23 mixture of the two methanesulfonates, rac-6a and $6 \mathbf{b}(2.5 \mathrm{~g}, 5.7 \mathrm{mmol})$ in dry THF $(50 \mathrm{~mL})$ at $-78^{\circ} \mathrm{C}$ was added ${ }^{t} \mathrm{BuOK}(703.6 \mathrm{mg}, 6.3 \mathrm{mmol})$. The reaction mixture was stirred at $-78^{\circ} \mathrm{C}$ for $1 \mathrm{~h}$ and then at RT for an additional $4 \mathrm{~h} .2 M$ aqueous hydrochloric acid was added and the organic solvent evaporated in vacuo. The residue was partitioned into water $(150 \mathrm{~mL})$ and dichloromethane $(100 \mathrm{~mL})$. The organic layer was separated and the aqueous solution extracted with dichloromethane $(2 \times 100 \mathrm{~mL})$. The combined organic layers were dried over anhydrous $\mathrm{MgSO}_{4}$, filtered, and the solvent evaporated in vacuo. Purification of the residue by flash chromatography on a $\mathrm{SiO}_{2}$ column (eluent: hexane/ethyl acetate, 1/1) afforded the bicyclic product rac-7 $(1.5 \mathrm{~g}, 4.3 \mathrm{mmol}$ ) as a white solid in $75 \%$ yield (from a 77/23 mixture of methanesulfonates $\mathrm{rac}-\mathbf{6 a}$ and $\mathbf{6 b}) . \mathrm{Mp}=165-166^{\circ} \mathrm{C}$. IR (neat) $v\left(\mathrm{~cm}^{-1}\right): 1730,1648,1578 .{ }^{1} \mathrm{H}$ $\operatorname{NMR}\left(\mathrm{CDCl}_{3}\right) \delta 7.83-7.85(\mathrm{~m}, 2 \mathrm{H}), 7.51-7.55(\mathrm{~m}, 1 \mathrm{H}), 7.43-7.47(\mathrm{~m}, 2 \mathrm{H}), 7.21(\mathrm{~d}, 1 \mathrm{H}, J=5.0$ $\mathrm{Hz}), 6.88-6.93(\mathrm{~m}, 2 \mathrm{H}), 4.30(\mathrm{dd}, 1 \mathrm{H}, J=4.8 \mathrm{~Hz}, J=4.5 \mathrm{~Hz}), 3.57(\mathrm{dd}, 1 \mathrm{H}, J=9.1 \mathrm{~Hz}, J=5.3$ $\mathrm{Hz}), 3.31$ (s, 3H), 2.50 (ddd, $1 \mathrm{H}, J=12.4 \mathrm{~Hz}, J=12.4 \mathrm{~Hz}, J=4.3 \mathrm{~Hz}), 2.40-2.45$ (m, 1H), 2.20 $(\mathrm{dd}, 1 \mathrm{H}, J=12.6 \mathrm{~Hz}, J=9.1 \mathrm{~Hz}), 1.95-2.04(\mathrm{~m}, 1 \mathrm{H}), 1.56-1.71(\mathrm{~m}, 2 \mathrm{H}) .{ }^{13} \mathrm{C}-\mathrm{NMR}\left(\mathrm{CDCl}_{3}\right) \delta$ $169.7,145.9$, 134.5, 131.8, 129.0, 128.3, 126.1, 125.3, 124.4, 73.0, 62.1, 51.5, 48.8, 40.7, 30.7, 29.4. Anal. Calcd. for $\mathrm{C}_{19} \mathrm{H}_{19} \mathrm{NO}_{3} \mathrm{~S}: \mathrm{C} 66.84, \mathrm{H} 5.61, \mathrm{~N} 4.10, \mathrm{~S}: 9.39$. Found C 66.90, H 5.52, $\mathrm{N}$ 4.04, S $9.42 \%$.

Resolution of methyl N-benzoyl-2-exo-(thien-2-yl)-7-azabicyclo[2.2.1]heptane-1carboxylate, (rac-7). HPLC resolution of rac-7 (1 g) dissolved in dichloromethane $(5 \mathrm{~mL})$ was carried out by successive injections, each of $200 \mu \mathrm{L}$, on a $150 \times 20 \mathrm{~mm}$ ID column filled with the 10-undecenoate/3,5-dimethylphenylcarbamate of cellulose bonded on allylsilica gel, using a 93/2/5 mixture of $n$-hexane/chloroform/2-propanol as eluent (flow rate, $18 \mathrm{~mL} \mathrm{~min}^{-1}$ ). A total of 27 injections was required, with one injection performed every $11 \mathrm{~min}$. Three separate fractions were collected. Evaporation of the first fraction provided $460 \mathrm{mg}$ of the enantiopure first eluted enantiomer $(1 S, 2 R, 4 R)-7$. The third fraction supplied $375 \mathrm{mg}$ of the last eluted enantiomer $(1 R, 2 S, 4 S)-7$, in $99.4 \%$ enantiomeric purity. The second fraction collected $(51 \mathrm{mg})$ contained a $62 / 38$ mixture of the first- and second- eluted enantiomers, $(1 S, 2 R, 4 R)-7 /(1 R, 2 S, 4 S)-7$.

Spectroscopic data for both $(1 S, 2 R, 4 R)-7$ and $(1 R, 2 S, 4 S)-7$ were the same as described above for rac-7: $(1 S, 2 R, 4 R)-7: \mathrm{Mp}=128-130^{\circ} \mathrm{C} .[\alpha]_{\mathrm{D}}=+57.4\left(c 1.0, \mathrm{CHCl}_{3}\right) ;(1 R, 2 S, 4 S)-7: \mathrm{Mp}=129-$ $130^{\circ} \mathrm{C} .[\alpha]_{\mathrm{D}}=-55.3\left(c 1.0, \mathrm{CHCl}_{3}\right)$. 
Synthesis of $(1 S, 2 R, 4 R)$ - and $(1 R, 2 S, 4 S)-N$-benzoyl-1-carbomethoxy-7-azabicyclo-[2.2.1] heptane-2-carboxylic acids, [(1S,2R,4R)-8 and (1R,2S,4S)-8]. A vigorously stirred solution of (1S,2R,4R)-7 or (1R,2S,4S)-7 (100 mg, $0.29 \mathrm{mmol})$ in $14 \mathrm{~mL}$ of a $1 / 1 / 1.5$ mixture of acetonitrile/carbon tetrachloride/water was treated with $\mathrm{NaIO}_{4}(1.2 \mathrm{~g}, 5.8 \mathrm{mmol})$ followed by $\mathrm{RuCl}_{3}$ (10 mg, $\left.0.04 \mathrm{mmol}\right)$ and the mixture stirred at RT. After $6 \mathrm{~h}$, additional water $(10 \mathrm{~mL})$ was added, the organic phase was separated, and the aqueous phase extracted with dichloromethane $(5 \times 50 \mathrm{~mL})$. The combined organic extracts were made basic with $1 \mathrm{MNaOH}$. The aqueous phase was separated, acidified with $1 M \mathrm{HCl}$, and extracted with dichloromethane $(3 \times 50 \mathrm{~mL})$. The combined extracts were washed with saturated brine, dried over anhydrous $\mathrm{MgSO}_{4}$, filtered, and concentrated in vacuo. Purification of the residue by flash column chromatography using dichloromethane/ethyl acetate (1/1) supplied the corresponding carboxylic acid $(1 S, 2 R, 4 R)-8$ or $(1 R, 2 S, 4 S)-8$ in $57 \%$ yield $(50 \mathrm{mg}, 0.17 \mathrm{mmol})$.

The spectroscopic data for each enantiomer were the same as described in the literature for $(1 S, 2 R, 4 R)-8:[\alpha]_{\mathrm{D}}=-23.5(c 0.2, \mathrm{MeOH})\left[\right.$ lit. $\left.^{13}[\alpha]_{\mathrm{D}}=-24.1(c 0.2, \mathrm{MeOH})\right] ;(1 R, 2 S, 4 S)-8:[\alpha]_{\mathrm{D}}=$ $+23.0(c 0.2, \mathrm{MeOH})\left[\right.$ lit. $\left.^{13}[\alpha]_{\mathrm{D}}=+22.3(c 0.2, \mathrm{MeOH})\right]$

\section{Acknowledgements}

This work was carried out with the financial support of Ministerio de Ciencia y Tecnología and FEDER (project PPQ2001-1834). A. M. Gil thanks CSIC for an I3P grant.

\section{References}

1. (a) Hruby, V. J.; Al-Obeidi, F. A.; Kazmierski, W. Biochem. J. 1990, 268, 249. (b) Balaram, P. Curr. Opin. Struct. Biol. 1992, 2, 845. (c) Liskamp, R. M. J. Recl. Trav. Chim. Pays-Bas 1994, 113, 1. (d) McDowell, R. S.; Artis, D. R. Ann. Rep. Med. Chem. 1995, 30, 265.

2. Hruby, V. J.; Balse, P. M. Curr. Med. Chem. 2000, 7, 945.

3. (a) Hruby, V. J.; Li, G.; Haskell-Luevano, C.; Shenderovich, M. Biopolymers 1997, 43, 219.

(b) Gibson, S. E.; Guillo, N.; Tozer, M. J. Tetrahedron 1999, 55, 585.

4. See: Sharma, R.; Lubell, W. D. J. Org. Chem. 1996, 61, 202, and references 1-7 therein.

5. (a) Holladay, M. W.; Lin, C. W.; May, C. S.; Garvey, D. S.; White, D. G.; Miller, T. R.; Wolfram, C. A.; Nadzan, A. M. J. Med. Chem. 1991, 34, 455. (b) Tilley, J. W.; Danho, W.; Madison, V.; Fry, D.; Swistok, J.; Makofske, R.; Michalewsky, J.; Schwartz, A.; Weatherford, S.; Triscari, J.; Nelson, D. J. Med. Chem. 1992, 35, 4249. (c) Kolodziej, S. A.; Nikiforovich, G. V.; Skeean, R.; Lignon, M.-F.; Martinez, J.; Marshall, G. R. J. Med. Chem. 1995, 38, 137. 
6. (a) Marshall, G. R. Tetrahedron 1993, 49, 3547. (b) Plucinska, K.; Kataoka, T.; Yodo, M.; Cody, W. L.; He, J. X.; Humblet, C.; Lu, G. H.; Lunney, E.; Major, T. C.; Panek, R. L.; Schelkun, P.; Skeean, R.; Marshall, G. R. J. Med. Chem. 1993, 36, 1902.

7. Kaczmarek, K.; Li, K.-M.; Sheean, R.; Dooley, D.; Humblet, C.; Lunney, E.; Marshall, G. R. In Peptides: Chemistry, Structure and Biology; Hodges, R. S.; Smith, J. A., Eds; ESCOM Science Publishers B. V.: Leiden, The Netherlands, 1994; p 687.

8. (a) Mosberg, H. I.; Kroona, H. B. J. Med. Chem. 1992, 35, 4498. (b) Mosberg, H. I.; Lomize, A. L.; Wang, C.; Kroona, H.; Heyl, D. L.; Sobczyk-Kojiro, K.; Ma, W.; Mousigian, C.; Porreca, F. J. Med. Chem. 1994, 37, 4371.

9. Nelson, R. D.; Gottlieb, D. I.; Balasubramanian, T. M.; Marshall, G. R. In Opioid Peptides: Medicinal Chemistry, NIDA Research Monograph 69; Rapaka, R. S. R. S.; Banett, G.; Hawks, R. L., Eds; 1986, p 204.

10. (a) Ghose, A. K.; Logan, M. E.; Treasurywala, A. M.; Wang, H.; Wahl, R. C.; Tomczuk, B.

E.; Gowravaram, M. R.; Jaeger, E. P.; Wendoloski, J. J. J. Am. Chem. Soc. 1995, 117, 4671.

(b) Hutton, J. J. Jr.; Marglin, A.; Witkop, B.; Kurtz, J.; Berger, A.; Undenfriend, S. Arch. Biochem. Biophys. 1968, 125, 779.

11. Han, W.; Pelletier, J. C.; Mersinger, L. J.; Kettner, C. A.; Hodge, C. N. Org. Lett. 1999, 1, 1875.

12. Han, W.; Pelletier, J. C.; Mersinger, L. J.; Hodge, C. N. Bioorg. Med. Chem. Lett. 1998, 8, 3615.

13. Gil, A. M.; Buñuel, E.; López, P.; Cativiela, C. Tetrahedron: Asymmetry 2004, 15, 811.

14. Gil, A. M.; Buñuel, E.; Jiménez, A. I.; Cativiela, C. Tetrahedron Lett. 2003, 44, 5999.

15. (a) Alcaide, B.; Almendros, P. Eur. J. Org. Chem. 2002, 10, 1595. (b) Brown, S. P.; Brochu, M. P.; Sinz, C. J.; MacMillan, D. W. C. J. Am. Chem. Soc. 2003, 125, 10808. (c) Notz, W.; Tanaka, F.; Barbas, C. F. III Acc. Chem. Res. 2004, 37, 580. (c) Northrup, A. B.; MacMillan, D. W. C. Science 2004, 305, 1752. (d) Northrup, A. B.; Mangion, I. K.; Hettche, F.; MacMillan, D. W. C. Angew. Chem., Int. Ed. 2004, 43, 2152. (e) Storer, R. I.; MacMillan, D. W. C. Tetrahedron 2004, 60, 7705.

16. (a) Campbell, J. A.; Rapoport, H. J. Org. Chem. 1996, 61, 6313. (b) Hart, B. P.; Rapoport, H. J. Org. Chem. 1999, 64, 2050. (c) Avenoza, A; Cativiela, C.; Fernández-Recio, M. A.; Peregrina, J. M. Tetrahedron: Asymmetry 1999, 10, 3999. (d) Lennox, J. R.; Turner, S. C.; Rapoport, H. J. Org. Chem. 2001, 66, 7078.

17. (a) Buñuel, E.; Gil, A. M.; Díaz-de-Villegas, M. D.; Cativiela, C. Tetrahedron 2001, 57, 6417. (b) Gil, A. M.; Buñuel, E.; Díaz-de-Villegas, M. D.; Cativiela, C. Tetrahedron: Asymmetry 2003, 14, 1479. (c) Gil, A. M.; Buñuel, E.; Cativiela, C. In Targets in Heterocyclic Systems. Chemistry and Properties; Attanasi, O. A.; Spinelli, D. Eds; Royal Society of Chemistry: Cambridge, in press.

18. Avenoza, A.; Barriobero, J. I.; Busto, J. H.; Cativiela, C.; Peregrina, J. M. Tetrahedron: Asymmetry 2002, 13, 625 . 
19. (a) Avenoza, A.; Busto, J. H.; Cativiela, C.; Peregrina, J. M. Tetrahedron Lett. 1995, 36, 7123. (b) Busto, J. H. Ph.D. Thesis, University of La Rioja, 1997.

20. Buñuel, E.; Cativiela, C.; Díaz-de-Villegas, M. D. Tetrahedron: Asymmetry 1996, 7, 1431.

21. Cativiela, C.; Díaz-de-Villegas, M. D.; Mayoral, J. A.; Meléndez, E. Synthesis 1983, 899.

22. Chen, Z.; Trudell, M. L. Chem. Rev. 1996, 96, 1179.

23. Oliveros, L.; Lopez, P.; Minguillón, C.; Franco, P. J. Liq. Chrom. 1995, 18, 1521.

24. (a) Cativiela, C.; Díaz-de-Villegas, M. D.; Jiménez, A. I.; López, P.; Marraud, M.; Oliveros, L. Chirality 1999, 11, 583. (b) Alías, M.; Cativiela, C.; Jiménez, A. I.; López, P.; Oliveros, L.; Marraud, M. Chirality 2001, 13, 48. (c) Jiménez, A. I.; López, P.; Oliveros, L.; Cativiela, C. Tetrahedron 2001, 57, 6019. (d) Royo, S.; López, P.; Jiménez, A. I.; Oliveros, L.; Cativiela, C. Chirality 2002, 14, 39. (e) Cativiela, C.; López, P.; Lasa, M. Eur. J. O. C. 2004, 3898. 